\title{
TGFBR / variants TGFBR /*6A and Int7G24A are not associated with an increased familial colorectal cancer risk
}

\author{
J Skoglund Lundin', J Vandrovcova', B Song ',2, X Zhou', M Zelada-Hedman', B Werelius', RS Houlston ${ }^{3}$ and \\ A Lindblom*,I \\ 'Department of Molecular Medicine and Surgery, Karolinska Institutet, CMM L8:02, S- 17176 Stockholm, Sweden; ${ }^{2}$ Department of Pathology, Dalian \\ Medical University, Dalian I 16027, China; ${ }^{3}$ Section of Cancer Genetics, Institute of Cancer Research, SM2 5NG, Sutton, Surrey, UK
}

Variants of the transforming growth factor-beta receptor type I (TGFBR I) gene, TGFBR I*6A and Int7G24A, have been suggested to act as low-penetrance tumour susceptibility alleles with TGFBRI*6A being causally responsible for some cases of familial colorectal cancer (CRC). We performed a case-control study of 262 unrelated familial CRC cases; 83 hereditary non-polyposis colorectal cancer (HNPCC) and 179 non-HNPCC. Patients were genotyped for TGFBR/*6A and Int7G24A and compared with 856 controls. Further, we screened the coding region of TGFBRI in affected members of a large family with CRC linked to 9q22.32-31.1. TGFBR / 6 A allelic frequency was not significantly different in all of the familial cases compared with controls $(0.107$ and 0.106 , respectively; $P=0.915)$. In a subgroup analysis allele frequencies were, however, different between HNPCC and non-HNPCC familial cases (0.157 and 0.084, respectively; $P=0.013)$. TGFBR I*6A genotype did not influence age of onset. Int7G24A allele frequencies were similar in cases and controls. No germ-line mutation was identified in the family with CRC linked to this chromosomal region. Our study provides no substantial support for the hypothesis that the polymorphic variants TGFBRI*6A or Int7G24A contribute to familial CRC risk. We cannot, however, exclude the possibility that TGFBRI variants have a modifying effect on inherited risk per se. British Journal of Cancer (2009) I 00, 1674-1679. doi:I0.1038/sj.bjc.6605054 www.bjcancer.com

Published online 28 April 2009

(c) 2009 Cancer Research UK

Keywords: colorectal cancer; adenoma; TGFBRI; TGFBRI*6A; Int7G24A

Colorectal cancer (CRC) is the third most common cause of cancer-related mortality in the Western countries, and in the United States it represents the second most common cause of cancer mortality (Parkin, 2001). Although $35 \%$ of all CRC seems to involve an inherited susceptibility (Lichtenstein et al, 2000). Mendelian predisposition syndromes associated with mutations in known genes (such as $A P C$, DNA mismatch repair genes (MMR), $M Y H, S M A D 4, B M P R 1 A / A L K 3$ and STK11/LKB1) collectively only account for $5 \%$ of disease burden (Lichtenstein et al, 2000; Lynch and de la Chapelle, 2003). The nature of the remaining heritability is undefined, but a model in which part of the inherited risk is conferred by common, low-penetrance alleles seems highly probable and has been the rationale for seeking to identify disease alleles through association analyses.

Transforming growth factor- $\beta$ (TGF- $\beta$ ) is a potent inhibitor of cell growth influencing the behaviour of a number of cancers (Derynck et al, 2001). The TGF- $\beta$ mediates its action through a heteromeric cell-surface complex of two types of transmembrane serine/threonine kinases, TGF- $\beta$ receptor type 1 (TGFBR 1 ) and type 2 (TGFBR2) (Lin et al, 1992; Ebner et al, 1993). The TGFBR2 gene is mutated in several cancer types with $\sim 90 \%$ of colon

*Correspondence: Professor A Lindblom;

E-mail: Annika.Lindblom@ki.se

Received 16 December 2008; revised 23 March 2009; accepted 30

March 2009; published online 28 April 2009 cancers characterized by MMR deficiency displaying frameshift mutations in a polyadenine tract of TGFBR2, which encodes the signal peptide of the expressed protein (Parsons et al, 1995).

A relatively common variant of the TGFBR 1 gene, TGFBR $1{ }^{\star} 6 A$, is caused by deletion of three GCG triplets coding for alanine within a nine alanine $(* 9 \mathrm{~A})$ repeat sequence of exon 1 , reportedly associated with less TGF- $\beta$ growth inhibitory signalling capacity than the native expressed protein (Chen et al, 1999; Pasche et al, 1999). In some epidemiological studies, the TGFBR $1^{\star} 6 A$ allele has been reported to be associated with an increased risk of a number of different malignancies, including CRC (Pasche et al, 1999; Chen et al, 2001; Baxter et al, 2002; Kaklamani and Pasche, 2005). In addition, the TGFBR $1^{\star} 6 A$ variant has been proposed to be directly causally responsible for a proportion of hereditary nonpolyposis colorectal cancer (HNPCC), especially those without MMR deficiency (Bian et al, 2005). Intriguingly, TGFBR1 maps to chromosome 9q22.32-31.1, a from several independent studies suggested CRC susceptibility locus (Wiesner et al, 2003; Kemp et al, 2006; Skoglund et al, 2006).

Another polymorphic variant of TGFBR1, Int7G24A, has also been implicated in cancer susceptibility, associations with kidney, bladder, breast and non-small cell lung cancer being reported (Chen et al, 1999, 2004; Zhang et al, 2003).

To further evaluate the relationship between the TGFBR1 variants and CRC risk we determined whether these variants contribute to familial CRC. Using a case-control design, we compared TGFBR $1^{\star} 6 A$ and Int7G24A allele frequencies in HNPCC 
and non-HNPCC familial CRC cases with population-based controls. We also examined whether germ-line TGFBR1 mutations are responsible for the CRC susceptibility locus on chromosome 9 by screening the entire coding region of TGFBR1 in affected members of a large family with adenoma and CRC linked to chromosome 9q22.32-31.1 (Skoglund et al, 2006).

\section{MATERIALS AND METHODS}

\section{Study population}

Two hundred and sixty-two families, ascertained through the Family Cancer Clinic at Karolinska University Hospital, Stockholm, Sweden during 1990-2006, were included in the study. A total of 83 families, all with a germ-line mutation in one of the MMR genes, were considered as HNPCC and 179 families were diagnosed and counselled as non-HNPCC according to our earlier published protocol (Lagerstedt Robinson et al, 2007). From each family one case was selected for case-control studies. The selection was made using the following priority order; (1) proband (when affected), (2) youngest CRC case or (3) youngest case with adenoma. Statistical analysis was carried out on CRC plus adenoma cases and CRC cases alone. Epidemiological studies have shown that a personal history of colon adenomas places one at increased risk of developing CRC (Neugut et al, 1993; Jacobson and Neugut, 1996; Liljegren et al, 2003). Furthermore, adenomas are over-represented in CRC families and first-degree relatives of patients with large adenomas are at increased risk of developing CRCs or large adenomas (Lindgren et al, 2002; Cottet et al, 2007). Removal of adenomatous polyps is associated with reduced CRC incidence (Muller and Sonnenberg, 1995; Winawer et al, 2000). Eight hundred and fifty-six blood donors from the Karolinska University Hospital, Stockholm, Sweden served as source of control DNA.

For mutation screening of TGFBR1, we analysed genomic DNA from a family with CRC and adenoma linked to chromosome 9q22.32-31.1. A full description of this family has been published earlier (Skoglund et al, 2006).

The study was undertaken in accordance with the Swedish legislation of ethical permission (2003:460) and the Stockholm regional ethical committee (Dnr: 2000/291, 2005/566) in accordance with the Declaration of Helsinki.

\section{Genotyping}

The TGFBR $1^{*} 6 A$ variant was determined by PCR amplification using fluorescently labelled primers Fwd- 5'-GAGGCGAG GTTTGCTGGGGTGAGG- $3^{\prime}$ and Rev- $5^{\prime}$-CATGTTTGAGAAAGAGC AGGAGCG-3'. Amplification was performed using the PlatinumTaq DNA polymerase and supplied protocol for GC-rich fragments (Invitrogen, Carlsbad, CA, USA). Amplified fragments were separated by electrophoresis on an ABI 377 semi-automated DNA Sequencer (Applied Biosystems, Bedford, MA, USA) and genotypes assigned using GENESCAN and GENOTYPER software (Applied Biosystems). A product size of $256 \mathrm{bp}$ corresponded to the most common allele, ${ }^{\star} 9 \mathrm{~A}$, whereas a product size of $247 \mathrm{bp}$ corresponded to the ${ }^{*} 6 \mathrm{~A}$ allele. Besides the ${ }^{\star} 9 \mathrm{~A}$ and ${ }^{*} 6 \mathrm{~A}$ alleles, we observed three rare alleles (Figure 1 ). The ${ }^{\star} 5 \mathrm{~A} /{ }^{\star} 9 \mathrm{~A}$ genotype was detected in one non-HNPCC case and one control case. Another two individuals with a ${ }^{*} 7 \mathrm{~A} /{ }^{*} 9 \mathrm{~A}$ genotype and one individual with a ${ }^{*} 9 \mathrm{~A} /{ }^{*} 10 \mathrm{~A}$ genotype was detected, all in the control group. All these rare alleles have been reported earlier (Pasche et al, 1999; Spillman et al, 2005). All ${ }^{*} 6 \mathrm{~A}$ homozygotes and ${ }^{*} 6 \mathrm{~A} /{ }^{*} 9 \mathrm{~A}$ heterozygotes and all samples with rare alleles were retyped after a second independent PCR amplification to confirm the allele calling.

Genotyping of the Int7G24A variant was performed by PCR amplification of intron 7 using primers Fwd- $5^{\prime}$-GGAGGTTCATC
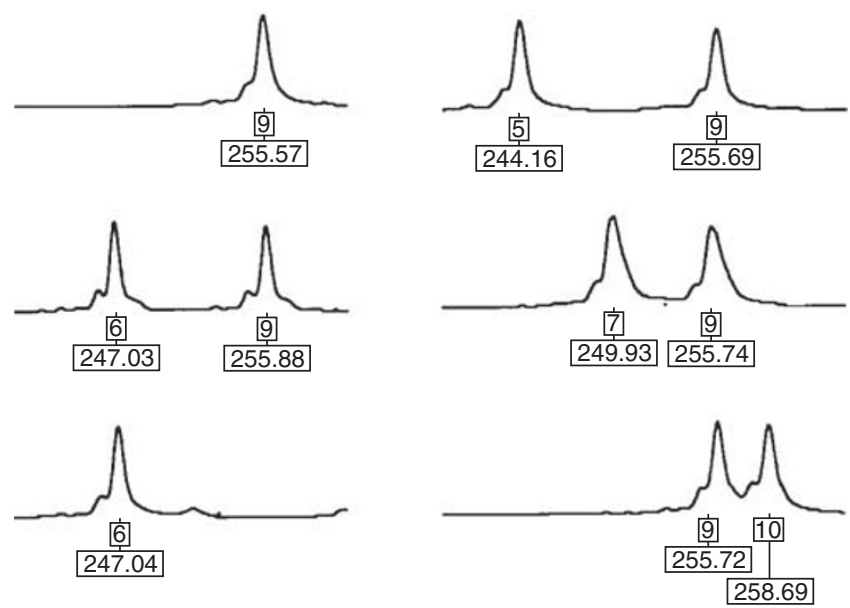

Figure I Representative electropherograms of the *9A/*9A, *6A/*9A, *6A/6A, *5A/9A, *7A*9A and *9A $/ 10 A$ genotypes. Allele and size in base pairs are indicated below each peak.
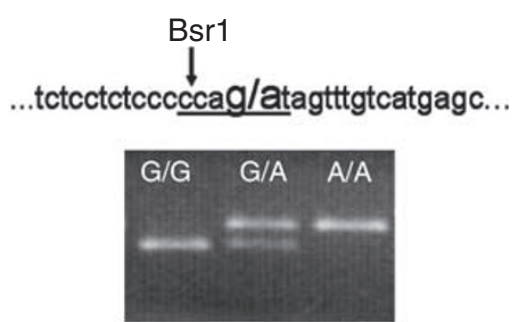

Figure 2 Genomic sequence surrounding the Int7G24A variant and a representative photograph of the PCR-RFLP analysis. The variant site is marked in bold and the Bsrl recognition site is underlined. Bsrl recognises and cuts the wild-type sequence (smaller band) whereas the variant abolishes the Bsrl restriction site (larger band).

CAAATATGGC- $3^{\prime}$ and Rev- ${ }^{\prime}$-CTCTGGCACTCGGTGACAT-3' followed by Bsr1 digestion and visualisation on a $2.5 \%$ agarose gel (Figure 2). For 85 samples, restriction enzyme digestion was replicated after a second independent PCR amplification to confirm the allele calling. Further details on genotyping can be obtained from the authors.

\section{Mutation screening of TGFBR1}

Mutational analysis of TGFBR1 was conducted on germ-line DNA from affected individuals in family 24 carrying the linked haplotype using a combination of denaturing high performance liquid chromatography (dHPLC) (exons $2-9+1091$ bp upstream of exon 1) and direct sequencing (exon $1+3^{\prime} \mathrm{UTR}$ ). Details on family 24 have been published earlier (Skoglund et al, 2006). Owing to stringent surveillance only one individual alive (Co-166) had developed CRC. Individual Co-166 was mutation screened for all fragments. The selection of additional individuals for mutation screening was carried out based on carrier status of the linked haplotype along with grade of affected status.

Screening for genomic deletions and rearrangements was performed using reverse transcriptase-PCR. RNA from two affected individuals (Co-186 and Co-213) plus two controls was extracted with the Qiagen RNeasy kit (Operon Biotechnologies, Huntsville, AL, USA) and reverse-transcribed with a first-strand synthesis kit (Amersham Biosciences, Piscataway, NJ, USA). Primer sequences and details of all the assays are available on request. 


\section{Statistical methods}

Risks associated with TGFBR1 genotypes were estimated by odds ratios (ORs) using unconditional logistic regression, and associated $95 \%$ confidence intervals (CIs) were computed. To test for population stratification the distribution of genotypes were tested for a departure from Hardy-Weinberg equilibrium. Differences in the distribution of continuous variables were compared using Mann-Whitney $U$-test or the statistics of Cuzick (1985) and Altman (1991) and between proportions by Fisher's exact test.

Table I Demographics and clinical status of HNPCC and non-HNPCC familial colorectal cancer cases

\begin{tabular}{|c|c|c|}
\hline Characteristics & $\begin{array}{l}\text { HNPCC }(n=83) \\
\text { No. (\%) of patients }\end{array}$ & $\begin{array}{c}\text { Non-HNPCC }(n=179) \\
\text { No. (\%) of patients }\end{array}$ \\
\hline \multicolumn{3}{|l|}{ Age } \\
\hline Mean (s.d.), years & $45(11)$ & $57(11)$ \\
\hline Range, years & $22-76$ & $28-84$ \\
\hline \multicolumn{3}{|l|}{ Sex } \\
\hline Male & $46(55)$ & $78(44)$ \\
\hline Female & $37(45)$ & I0I (56) \\
\hline \multicolumn{3}{|l|}{ Clinical manifestation } \\
\hline CRC & $82(99)$ & $132(74)$ \\
\hline Adenoma & $1(1)$ & $47(26)$ \\
\hline \multicolumn{3}{|l|}{ Fulfillment of Guidelines ${ }^{\mathrm{a}}$} \\
\hline Amsterdam criteria I & $42(56)$ & $17(9)$ \\
\hline Amsterdam criteria II & $53(7 \mathrm{I})$ & $19(11)$ \\
\hline Bethesda Guidelines & $73(97)$ & $140(78)$ \\
\hline \multicolumn{3}{|l|}{ MMR gene mutation } \\
\hline MLHI & $40(48)$ & - \\
\hline $\mathrm{MSH} 2$ & $35(42)$ & - \\
\hline MSH6 & $8(10)$ & - \\
\hline
\end{tabular}

Abbreviations: $\mathrm{CRC}=$ colorectal cancer; $\mathrm{HNPCC}=$ hereditary non-polyposis colorectal cancer; $M M R=$ mismatch repair. ${ }^{a}$ For a definition of the Amsterdam criteria I, see Vasen et al (1991); extended Amsterdam II criteria, see Vasen et al (1999); Bethesda guidelines, see Rodriguez-Bigas et al (1997) and Umar et al (2004).
Confidence limits for sequence changes among cases were computed under the assumption that frequencies followed a Poisson distribution. All statistical analyses were performed using STATA Version 7.0 (Stata Corporation, College Station, TX, USA). A P-value of 0.05 was considered statistically significant in all analyses.

\section{RESULTS}

The characteristics of the study participants are detailed in Table 1. Cases from HNPCC families were diagnosed with CRC younger than those from non-HNPCC families (45 years vs 57 years, respectively; $P<0.01)$ consistent with ascertainment selection.

The observed frequencies of TGFBR $1^{\star} 6 A$ genotypes in cases and controls were in accordance with Hardy-Weinberg laws of equilibrium $(P=0.35$ and 1.00 in familial non-HNPCC and HNPCC cases; $P=0.86$ in controls), providing no evidence of population stratification within the dataset. The frequency of TGFBR $1^{*} 6$ A was not significantly different between controls (0.106, 95\% CI: $0.102-0.135)$ and all familial cases $(0.107,95 \%$ CI: $0.082-0.137$; Table 2A). Confining the affection status to a diagnosis of CRC only and excluding adenomas did not change the results much (0.117, 95\% CI: $0.087-0.151$; Table 2B).

Eighty-three of the cases had HNPCC and 179 had non-HNPCC hereditary CRC. Among those with non-HNPCC; 26 (14.5\%) and two $(1.1 \%)$ were hetero- and homozygous for the TGFBR $1^{\star} 6 A$ allele, respectively (TGFBR $1^{\star} 6 A$ allele frequency 0.084 ). Of the 83 cases with HNPCC; $22(26.5 \%)$ and two $(2.4 \%)$ were TGFBR $1^{\star} 6 A$ heterozygotes and homozygotes, respectively $\left(T G F B R 1^{*} 6 A\right.$ allele frequency 0.157$)$. Of the $24 T G F B R 1^{\star} 6 A$ carriers; 10 had a $M L H 1$ mutation, 11 had a $M S H 2$ mutation and three had a MSH6 mutation. Although the frequency of the TGFBR $1{ }^{\star} 6 A$ allele was similar in non-HNPCC familial cases and controls (0.084 and 0.106 , respectively; $P=0.23$ ), the frequency in HNPCC cases was markedly elevated $(0.157 ; P=0.045)$ compared with the controls. Hence, there was an apparent difference in TGFBR $1^{\star} 6 \mathrm{~A}$ allele frequency between HNPCC and non-HNPCC familial cases $(0.157$ and 0.084 , respectively; $P=0.013$ ). Table $2 \mathrm{~A}$ details the ORs of CRC and adenoma and corresponding $95 \%$ CIs associated with TGFBR $1^{*} 6 A$ hetero- and homozygosity in the two familial CRC groups. When performing test for association restricting affection

Table 2A Association between TGFBR/*6A genotypes and risk of colorectal cancer and adenoma

\begin{tabular}{|c|c|c|c|c|c|c|c|}
\hline \multirow[b]{2}{*}{ Exon IGenotype } & \multirow{2}{*}{$\begin{array}{l}\text { Controls } n=856^{a} \\
\text { No. of cases (\%) }\end{array}$} & \multicolumn{2}{|c|}{ All familial cases $n=262^{a}$} & \multicolumn{2}{|c|}{ Non-HNPCC $n=179^{a}$} & \multicolumn{2}{|c|}{ HNPCC $n=83$} \\
\hline & & No. of cases (\%) & OR (95\% Cl) & No. of cases (\%) & OR (95\% Cl) & No. of cases (\%) & OR $(95 \% \mathrm{Cl})$ \\
\hline $9 \mathrm{~A} / 6 \mathrm{~A}$ & $160(18.7)$ & $48(18.3)$ & $0.98(0.68-1.40)$ & $26(14.5)$ & $0.74(0.47-1.16)$ & $22(26.5)$ & $1.59(0.95-2.67)$ \\
\hline $6 \mathrm{~A} / 6 \mathrm{~A}$ & $10(1.2)$ & $4(1.5)$ & $1.31(0.4 \mid-4.21)$ & $2(1.1)$ & $0.91(0.20-4.19)$ & $2(2.4)$ & $2.30(0.50-10.8)$ \\
\hline $9 \mathrm{~A} / 6 \mathrm{~A}$ and $6 \mathrm{~A} / 6 \mathrm{~A}$ & $170(19.9)$ & $52(19.8)$ & $1.00(0.7 \mid-1.41)$ & $28(15.6)$ & $0.75(0.48-1.16)$ & $24(28.9)$ & $1.63(0.99-2.70)$ \\
\hline $6 \mathrm{~A}$ frequency & 0.106 & 0.107 & & 0.084 & & 0.157 & \\
\hline
\end{tabular}

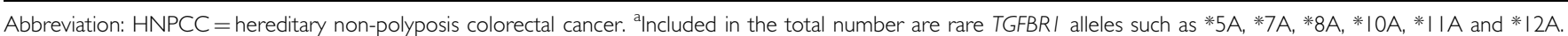

Table 2B Association between TGFBRI*6A genotypes and risk of colorectal cancer

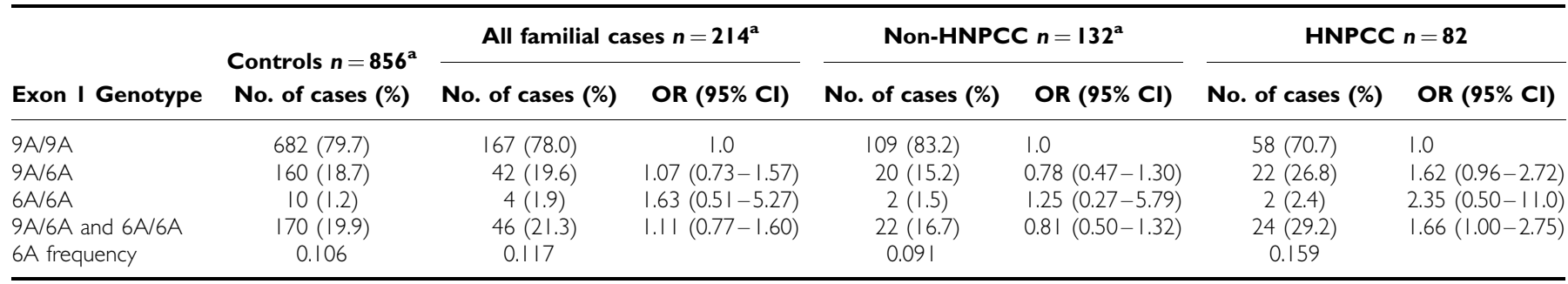

Abbreviation: HNPCC = hereditary non-polyposis colorectal cancer. ${ }^{a}$ Included in the total number are rare TGFBR I alleles such as *5A, *7A, *8A, *IOA, *I।A and * I2A. 
Table 3A Association between Int7G24A genotypes and risk of colorectal cancer and adenoma

\begin{tabular}{|c|c|c|c|c|c|c|c|}
\hline \multirow[b]{2}{*}{ Int7G24A Genotype } & \multirow{2}{*}{$\begin{array}{l}\text { Controls } n=853 \\
\text { No. of cases (\%) }\end{array}$} & \multicolumn{2}{|c|}{ All familial cases $n=262$} & \multicolumn{2}{|c|}{ Non-HNPCC $n=179$} & \multicolumn{2}{|c|}{ HNPCC $n=83$} \\
\hline & & No. of cases (\%) & OR $(95 \% \mathrm{Cl})$ & No. of cases (\%) & OR (95\% Cl) & No. of cases (\%) & OR (95\% Cl) \\
\hline
\end{tabular}

Abbreviation: HNPCC = hereditary non-polyposis colorectal cancer.

Table 3B Association between Int7G24A genotypes and risk of colorectal cancer

\begin{tabular}{|c|c|c|c|c|c|c|c|}
\hline Int7G24A Genotype & $\begin{array}{l}\text { Controls } n=853 \\
\text { No. of cases (\%) }\end{array}$ & \multicolumn{2}{|c|}{ All familial cases $n=214$} & \multicolumn{2}{|c|}{ Non-HNPCC $n=132$} & \multicolumn{2}{|c|}{ HNPCC $n=82$} \\
\hline $\mathrm{G} / \mathrm{A}$ & $265(31.1)$ & $67(31.3)$ & $1.05(0.76-1.45)$ & $46(34.8)$ & $1.21(0.82-1.79)$ & $21(25.6)$ & $0.81(0.48-1.36)$ \\
\hline A/A & $29(3.4)$ & $12(5.6)$ & $1.71(0.85-3.45)$ & $6(4.5)$ & $1.45(0.58-3.59)$ & $6(7.3)$ & $2.10(0.84-5.29)$ \\
\hline $\mathrm{G} / \mathrm{A}$ and $\mathrm{A} / \mathrm{A}$ & $294(34.5)$ & $79(36.9)$ & I.II $(0.82-1.52)$ & $52(39.4)$ & $1.24(0.85-1.80)$ & $27(32.9)$ & $0.93(0.58-1.51)$ \\
\hline A frequency & 0.189 & 0.213 & & 0.220 & & 0.201 & \\
\hline
\end{tabular}

Abbreviation: HNPCC = hereditary non-polyposis colorectal cancer.

status in cases to CRC (non-HNPCC, $n=132$; HNPCC, $n=82$ ), corresponding ORs were similar (Table 2B).

To further explore the possibility that carrier status might affect CRC risk we compared the age of onset of CRC in TGFBR $1^{\star} 6 \mathrm{~A}$ carriers and non-carriers. There was no association between age at diagnosis of CRC and TGFBR $1^{\star} 6 A$ genotype (data not shown). Comparison of the cumulative distribution curves also showed no significant difference in carriers compared with non-carriers. Among familial non-HNPCC cases the average age at cancer diagnosis in TGFBR $1^{\star} 6 \mathrm{~A}$ carriers and non-carriers was 58.4 years (s.d., 13.0) and 56.8 years (s.d., 10.6), respectively. Corresponding ages at diagnosis in carriers and non-carriers in HNPCC cases was 43.3 years (s.d., 11.0) and 45.7 years (s.d., 10.6), respectively.

In the study by Bian et al (2005), the highest TGFBR ${ }^{*} 6 A$ frequency was found among MMR mutation-negative cases with MSI-negative tumours. Data on tumour DNA samples evaluated for MSI status were available from 249 of the cases. Among all familial cases, $T G F B R 1^{\star} 6 A$ carrier frequency was not significantly different in MSI-positive cases compared with MSI negative $(P=0.17)$. Among HNPCC cases with MSI tumours (MMR/MSI positive) over-representation of TGFBR $1^{\star} 6 A$ carriers was evident, albeit non-significantly compared with the controls (data not shown). Subdividing the whole sample set by Amsterdam criteria and MMR status showed the highest TGFBR ${ }^{*} 6 A$ allelic frequency in Amsterdam criteria-positive families with a detected MMR gene mutation (0.198). On the contrary, the allelic frequency was zero in Amsterdam criteria-negative families with no detected MMR mutation.

The Int7G24A variant was successfully genotyped in 262 familial CRC cases, 179 non-HNPCC and 83 HNPCC, and 853 controls. The observed frequencies of Int7G24A genotypes in cases and controls were in accordance with Hardy-Weinberg laws of equilibrium $(P=1.00$ and 0.09 in familial non-HNPCC and HNPCC cases; $P=0.82$ in controls). There were no differences in allele or genotype frequencies between cases and controls or between the different types of familial CRC (Tables 3A and 3B).

In an earlier study, we have shown linkage of CRC and colorectal adenomas to chromosome 9q22.32-31.1 in a large Swedish family (family 24) (Skoglund et al, 2006). To exclude the possibility that sequence variation in TGFBR1 is responsible for the linkage in the family, we screened for germ-line mutations in affected family members. The TGFBR $1^{*} 6 A$ and Int7G24A variants were not on the linked haplotype. Two individuals (Co-213 and Co-219) were heterozyogous TGFBR $1^{\star} 6 A$ carriers. The remaining seven individuals with the linked haplotype were ${ }^{*} 9 \mathrm{~A}$ homozygous. For the Int7G24A variant; the two individuals screened for this fragment (Co-166 and Co-648) were not carriers of this variant. No sequence change was detected on the linked haplotype.

\section{DISCUSSION}

Some studies have reported an over-representation of TGFBR $1^{*} 6 A$ in individuals with a number of different cancers fuelling speculation by Pasche et al (2004) that the TGFBR ${ }^{*} 6 A$ allele represents a low-penetrance allele with pleiotropic effects. The same research group reported a case-control study comparing TGFBR $1^{\star} 6 A$ allelic frequency among HNPCC patients subdivided by first MMR gene mutations status and second tumour MSI status, observing a markedly elevated frequency of TGFBR $1^{*} 6 A$ carriers among MMR gene mutation-negative cases with the highest frequency among cases with MSI-negative tumours (Bian et al, 2005). On this basis they postulated that the TGFBR $1^{\star} 6 A$ allele may be causally responsible for a proportion of non-HNPCC occurrence.

In contrast to Bian et al (2005) in our study TGFBR $1{ }^{*} 6 A$ allelic frequency was not significantly different in all of the familial cases compared with controls. Moreover, in a subgroup analysis (which inevitably invokes the issue of multiple testing and apparent paradoxes) allele frequencies were only significantly different in HNPCC cases with a known MMR genetic defect, indicating a possible role if any as a modifying factor in HNPCC families. Further subdivision by MMR- and MSI status confirms this observation however, groups are small and differences were not significant. Further studies are needed to confirm this observation.

In our study, 48 cases affected with adenomas were included in the analysis. However, as shown in Table $2 \mathrm{~b}$ excluding these did not change the results indicating that the TGFBR $1^{*} 6 A$ variant confers the same increased risk for adenoma as for CRC in these families.

The intronic variant, Int7G24A, has been variously associated with an increased risk of kidney-, bladder- and breast cancer 
(Chen et al, 2004, 2006). Although our analyses were based on a smaller control dataset than that used for evaluation of TGFBR $1{ }^{*} 6 A$, we found no real evidence that Int7G24A influences CRC risk.

The pivotal role TGFBR1 plays in tumour development makes the hypothesis that germ-line variation in the gene may influence CRC susceptibility an attractive concept. A recent study has reported that germ-line allele-specific expression (ASE) of TGFBR1 is a quantitative trait detectable in $10-20 \%$ of CRC patients and $1-3 \%$ of the population (Valle et al, 2008). Moreover it was proposed ASE is dominantly inherited trait, if confirmed these findings are compatible for this association being responsible for $>50 \%$ of the excess familial risk of CRC. Paradoxically, although two major TGFBR1 haplotypes were predominant among ASE cases (one of the two major haplotypes included TGFBR $1^{\star} 6 A$ and overall $50 \%$ of ASE cases carried the TGFBR $1^{*} 6 A$ variant) no causal variant was identified.

In contrast to the findings of Valle et al (2008) in a large casecontrol study and meta-analysis of eight earlier published studies of the relationship between TGFBR $1^{\star} 6 A$ and CRC, we found little evidence for the tenet that germ-line variation in the gene defined by this variant significantly influences CRC risk (Skoglund et al, 2007).

For this study, we had 262 families available for analysis. On the basis of published estimations of sample size needed for achieving adequate power to detect association our data set has limited power. However, analysing familial cases provide a means of generating a genetically enriched dataset with increased power to show associations compared with using unselected cases (Houlston and Peto, 2003). Without appropriate adjustment, however, derived genotypic risks computed are inflated, hence the upper confidence limits of the risk of CRC associated with the variants in our study will be overoptimistic.

As source of controls, we have employed blood donors. No data, because of policy of anonymity, was available for age, ethnicity, medical- or family history for these individuals. However, it is unlikely that this will have significantly influenced study findings as any age or gender difference from controls will be minimal. Furthermore, although the ethnicity data on blood donors was not available these individuals were drawn from the same demographic region as the cases analysed making the probability of confounding from population stratification unlikely. Blood donors constitute a healthy cohort with a risk for later onset diseases, such as CRC close to that of the general population. Still, even if the controls are representative for the general population, cases included are not consecutive but constitute a cohort genetically enriched for risk alleles. Therefore, we used OR rather than the relative risk to calculate the risk associated with the variants.

Mutational analysis of TGFBR1 in the earlier published family 24 with CRC and adenoma linked to chromosome 9q22.32-31.1 (Skoglund et al, 2006) showed no sequence changes on the linked haplotype. Furthermore, the linked haplotype carried the normal sequence for the two studied variants, TGFBR $1^{\star} 6 A$ and Int7G24A. Therefore, we can exclude these variants as disease causing in this family. This is in accordance with two recent studies where the TGFBR $1^{\star} 6 A$ variant was investigated in a sample linked to this locus and excluded as the disease-causing variant (Kemp et al, 2006; Daley et al, 2007). The fact that the linked haplotype carried the normal sequence for the two studied variants TGFBR $1{ }^{\star} 6 A$ and Int7G24A means it is therefore different from at least one of the TGFBR1 ASE haplotypes reported by Valle et al (2008) which carried the TGFBR $1 * 6 A$ variant.

We cannot exclude the possibility that variants of TGFBR1 are associated with a small CRC risk modifying the impact of other gene effects. However, on the basis of our findings it seems unlikely that variation in TGFBR1 defined by the TGFBR ${ }^{*} 6 \mathrm{~A}$ and the Int7G24A makes a significant contribution to familial CRC risk.

\section{ACKNOWLEDGEMENTS}

This study was supported by the Cancer and Allergy Foundation, the Gustav the fifth Jubilee Foundation, the Nilson-Ehle Foundation, the Anders Otto Swärd Foundation, the FoU Foundation, the Swedish Research Council and the Swedish Cancer Society.

\section{REFERENCES}

Altman DG (1991) Categorising continuous variables. Br J Cancer 64: 975 Baxter SW, Choong DY, Eccles DM, Campbell IG (2002) Transforming growth factor beta receptor 1 polyalanine polymorphism and exon 5 mutation analysis in breast and ovarian cancer. Cancer Epidemiol Biomarkers Prev 11: $211-214$

Bian Y, Caldes T, Wijnen J, Franken P, Vasen H, Kaklamani V, Nafa K, Peterlongo P, Ellis N, Baron JA, Burn J, Moeslein G, Morrison PJ, Chen Y, Ahsan H, Watson P, Lynch HT, de la Chapelle A, Fodde R, Pasche B (2005) TGFBR1*6A may contribute to hereditary colorectal cancer. J Clin Oncol 23: $3074-3078$

Chen T, de Vries EG, Hollema H, Yegen HA, Vellucci VF, Strickler HD, Hildesheim A, Reiss M (1999) Structural alterations of transforming growth factor-beta receptor genes in human cervical carcinoma. Int $J$ Cancer 82: $43-51$

Chen T, Jackson C, Costello B, Singer N, Colligan B, Douglass L, Pemberton J, Deddens J, Graff JR, Carter JH (2004) An intronic variant of the TGFBR1 gene is associated with carcinomas of the kidney and bladder. Int J Cancer 112: $420-425$

Chen T, Jackson CR, Link A, Markey MP, Colligan BM, Douglass LE, Pemberton JO, Deddens JA, Graff JR, Carter JH (2006) Int7G24A variant of transforming growth factor-beta receptor type $\mathrm{I}$ is associated with invasive breast cancer. Clin Cancer Res 12: $392-397$

Chen T, Triplett J, Dehner B, Hurst B, Colligan B, Pemberton J, Graff JR, Carter JH (2001) Transforming growth factor-beta receptor type I gene is frequently mutated in ovarian carcinomas. Cancer Res 61: $4679-4682$

Cottet V, Pariente A, Nalet B, Lafon J, Milan C, Olschwang S, Bonaiti-Pellie C, Faivre J, Bonithon-Kopp C (2007) Colonoscopic screening of first- degree relatives of patients with large adenomas: increased risk of colorectal tumors. Gastroenterology 133: 1086-1092

Cuzick J (1985) A method for analysing case-control studies with ordinal exposure variables. Biometrics 41: 609-621

Daley D, Morgan W, Lewis S, Willis J, Elston RC, Markowitz SD, Wiesner GL (2007) Is TGFBR $1^{\star} 6 \mathrm{~A}$ a susceptibility allele for nonsyndromic familial colorectal neoplasia? Cancer Epidemiol Biomarkers Prev 16: 892 - 894

Derynck R, Akhurst RJ, Balmain A (2001) TGF-beta signaling in tumor suppression and cancer progression. Nat Genet 29: 117-129

Ebner R, Chen RH, Shum L, Lawler S, Zioncheck TF, Lee A, Lopez AR, Derynck R (1993) Cloning of a type I TGF-beta receptor and its effect on TGF-beta binding to the type II receptor. Science 260: 1344-1348

Houlston RS, Peto J (2003) The future of association studies of common cancers. Hum Genet 112: 434-435

Jacobson JS, Neugut AI (1996) Epidemiology of gastrointestinal polyps. Surg Oncol Clin N Am 5: $531-544$

Kaklamani V, Pasche B (2005) Transforming growth factor beta and breast cancer. Cancer Treat Res 126: $129-156$

Kemp ZE, Carvajal-Carmona LG, Barclay E, Gorman M, Martin L, Wood W, Rowan A, Donohue C, Spain S, Jaeger E, Evans DG, Maher ER, Bishop T, Thomas H, Houlston R, Tomlinson I (2006) Evidence of linkage to chromosome $9 \mathrm{q} 22.33$ in colorectal cancer kindreds from the United Kingdom. Cancer Res 66: 5003-5006

Lagerstedt Robinson K, Liu T, Vandrovcova J, Halvarsson B, Clendenning M, Frebourg T, Papadopoulos N, Kinzler KW, Vogelstein B, Peltomaki P, Kolodner RD, Nilbert M, Lindblom A (2007) Lynch syndrome (hereditary nonpolyposis colorectal cancer) diagnostics. J Natl Cancer Inst 99: 291 - 299 
Lichtenstein P, Holm NV, Verkasalo PK, Iliadou A, Kaprio J, Koskenvuo M, Pukkala E, Skytthe A, Hemminki K (2000) Environmental and heritable factors in the causation of cancer - analyses of cohorts of twins from Sweden, Denmark, and Finland. N Engl J Med 343: 78-85

Liljegren A, Lindblom A, Rotstein S, Nilsson B, Rubio C, Jaramillo E (2003) Prevalence and incidence of hyperplastic polyps and adenomas in familial colorectal cancer: correlation between the two types of colon polyps. Gut 52: $1140-1147$

Lin HY, Wang XF, Ng-Eaton E, Weinberg RA, Lodish HF (1992) Expression cloning of the TGF-beta type II receptor, a functional transmembrane serine/threonine kinase. Cell 68: 775-785

Lindgren G, Liljegren A, Jaramillo E, Rubio C, Lindblom A (2002) Adenoma prevalence and cancer risk in familial non-polyposis colorectal cancer. Gut 50: $228-234$

Lynch HT, de la Chapelle A (2003) Hereditary colorectal cancer. N Engl J Med 348: 919-932

Muller AD, Sonnenberg A (1995) Prevention of colorectal cancer by flexible endoscopy and polypectomy. A case-control study of 32702 veterans. Ann Intern Med 123: $904-910$

Neugut AI, Jacobson JS, De Vivo I (1993) Epidemiology of colorectal adenomatous polyps. Cancer Epidemiol Biomarkers Prev 2: 159-176

Parkin DM (2001) Global cancer statistics in the year 2000. Lancet Oncol 2: $533-543$

Parsons R, Myeroff LL, Liu B, Willson JK, Markowitz SD, Kinzler KW, Vogelstein B (1995) Microsatellite instability and mutations of the transforming growth factor beta type II receptor gene in colorectal cancer. Cancer Res 55: 5548-5550

Pasche B, Kolachana P, Nafa K, Satagopan J, Chen YG, Lo RS, Brener D, Yang D, Kirstein L, Oddoux C, Ostrer H, Vineis P, Varesco L, Jhanwar S, Luzzatto L, Massague J, Offit K (1999) TbetaR-I(6A) is a candidate tumor susceptibility allele. Cancer Res 59: $5678-5682$

Pasche B, Kaklamani V, Hou N, Young T, Rademaker A, Peterlongo P, Ellis N, Offit K, Caldes T, Reiss M, Zheng T (2004) TGFBR1 ${ }^{\star} 6$ A and cancer: a metaanalysis of 12 case-control studies. J Clin Oncol 22: 756-758

Rodriguez-Bigas MA, Boland CR, Hamilton SR, Henson DE, Jass JR, Khan PM, Lynch H, Perucho M, Smyrk T, Sobin L, Srivastava S (1997) A National Cancer Institute Workshop on Hereditary Nonpolyposis Colorectal Cancer Syndrome: meeting highlights and Bethesda guidelines. J Natl Cancer Inst 89: 1758 - 1762

Skoglund J, Djureinovic T, Zhou XL, Vandrovcova J, Renkonen E, Iselius L, Bisgaard ML, Peltomaki P, Lindblom A (2006) Linkage analysis in a large Swedish family supports the presence of a susceptibility locus for adenoma and colorectal cancer on chromosome 9q22.32-31.1. J Med Genet 43: e7

Skoglund J, Song B, Dalen J, Dedorson S, Edler D, Hjern F, Holm J, Lenander C, Lindforss U, Lundqvist N, Olivecrona H, Olsson L, Pahlman L, Rutegard J, Smedh K, Tornqvist A, Houlston RS, Lindblom A (2007) Lack of an association between the TGFBR ${ }^{\star} 6 \mathrm{~A}$ variant and colorectal cancer risk. Clin Cancer Res 13: 3748-3752

Spillman MA, Schildkraut JM, Halabi S, Moorman P, Calingaert B, Bentley RC, Marks JR, Murphy S, Berchuck A (2005) Transforming growth factor beta receptor I polyalanine repeat polymorphism does not increase ovarian cancer risk. Gynecol Oncol 97: 543-549

Umar A, Boland CR, Terdiman JP, Syngal S, de la Chapelle A, Ruschoff J, Fishel R, Lindor NM, Burgart LJ, Hamelin R, Hamilton SR, Hiatt RA, Jass J, Lindblom A, Lynch HT, Peltomaki P, Ramsey SD, Rodriguez-Bigas MA, Vasen HF, Hawk ET, Barrett JC, Freedman AN, Srivastava S (2004) Revised Bethesda Guidelines for hereditary nonpolyposis colorectal cancer (Lynch syndrome) and microsatellite instability. J Natl Cancer Inst 96: $261-268$

Valle L, Serena-Acedo T, Liyanarachchi S, Hampel H, Comeras I, Li Z, Zeng Q, Zhang HT, Pennison MJ, Sadim M, Pasche B, Tanner SM, de la Chapelle A (2008) Germline allele-specific expression of TGFBR1 confers an increased risk of colorectal cancer. Science 321: 1361-1365

Vasen HF, Mecklin JP, Khan PM, Lynch HT (1991) The International Collaborative Group on Hereditary Non-Polyposis Colorectal Cancer (ICG-HNPCC). Dis Colon Rectum 34: 424-425

Vasen HF, Watson P, Mecklin JP, Lynch HT (1999) New clinical criteria for hereditary nonpolyposis colorectal cancer (HNPCC, Lynch syndrome) proposed by the International Collaborative group on HNPCC. Gastroenterology 116: $1453-1456$

Wiesner GL, Daley D, Lewis S, Ticknor C, Platzer P, Lutterbaugh J, MacMillen M, Baliner B, Willis J, Elston RC, Markowitz SD (2003) A subset of familial colorectal neoplasia kindreds linked to chromosome 9q22.2-31.2. Proc Natl Acad Sci USA 100: $12961-12965$

Winawer SJ, Stewart ET, Zauber AG, Bond JH, Ansel H, Waye JD, Hall D, Hamlin JA, Schapiro M, O'Brien MJ, Sternberg SS, Gottlieb LS (2000) A comparison of colonoscopy and double-contrast barium enema for surveillance after polypectomy. National Polyp Study Work Group. $N$ Engl J Med 342: 1766-1772

Zhang HT, Fei QY, Chen F, Qi QY, Zou W, Wang JC, Zhang RM, Tao SH, Chen XF, Luo ZW (2003) Mutational analysis of the transforming growth factor beta receptor type I gene in primary non-small cell lung cancer. Lung Cancer 40: 281-287 